\title{
Prayers at the Nuptial Bed: Spiritual Guidance on Consummation in Seventeenth-Century Dutch Epithalamia
}

\author{
Jungyoon Yang
}

The first volume of marriage registers from the Oude Kerk, Amsterdam's principal parish church at the time, recorded a momentous event in the city's history that took place in May 1578. It was the so-called Alteration, when the city's Catholic government was deposed and replaced by a Protestant one. ${ }^{1}$ Unlike the Catholics, Calvinists did not regard marriage as a sacrament, but the ministers of the newly Reformed Oude Kerk nevertheless continued recording the unions they solemnized in the church as if nothing had happened: ${ }^{2}$

Starting in the year 1565 , first the Roman priests recorded herein all the persons whom they married in their manner up until the year 1578 , the 23rd day of May [...]. And also recorded herein in that same aforesaid year of 1578 , the 11th of May, are the names of the very first persons who were married in God's congregation by a servant of the holy Gospel. ${ }^{3}$

Calvin had said that marriage was 'a good and holy ordinance of God', but, he continued, 'so also are agriculture, architecture, shoemaking, hair-cutting

1 On church wedding ceremonies after the Alteration, see Roodenburg H., Onder censuur. De kerkelijke tucht in de gereformeerde gemeente van Amsteradam, 1578-1700 (Hilversum: 1990) 90-95.

2 Nierop L. van, "De bruidegoms van Amsterdam van 1578 tot 1601", Tijdschrift voor Geschiedenis 48 (1933) 337-359; 49 (1934) 136-160, 329-344; 52 (1937) 144-162; Knappert L., "De gereformeerde kerk in haren strijd om het wettig huwelijk", Nederlands Archief voor Kerkgeschiedenis 2 (1903) 217-275, 359-396; Haks D., Huwelijk en gezin in Holland in de $17 d e$ en 18de eeuw. Processtukken en moralisten over aspecten van het laat 17de- en 18de-eeuwse gezinsleven (Assen: 1982) 114-116.

3 Trouwregisters Oude Kerk, inventory no. 969 (Amsterdam: Stadsarchief) 1: 'Beginnende Anno 1565 voor eerst hebben de Roemsche priesters hier in aengetekent Alle die Parsoonen die sijluiden op hare wijse getrout hebben tot de Jare 1578 den drieentwintichste dach maijo [...]. Ende intselfde voorsch. 1578en Jaer den elfden maijo soo is hier in mede aengetekent de namen vandie parsoonen die alder eerst door een dienaer des he Evangelije in godts gemeinte sijn getrout'.

(C) JUNGYOON YANG, 2019 | DOI:10.1163/9789004375888_011

This is an open access chapter distributed under the terms of the prevailing CC-BY-NC-ND License at the time of publication. 
legitimate ordinances of God, but they are not sacraments.' ${ }^{4}$ A Calvinist marriage was a covenant involving the entire religious community, and the minister's task was restricted to blessing the couple and instructing them in their spiritual duties.

The new ecclesiastical rite dictated by Protestant dogma was followed not long afterwards in the northern Netherlands by a revival of the genre of epithalamia, verses celebrating a wedding. ${ }^{5}$ It was a development that was embraced with great enthusiasm by Flemish immigrants who had fled the Catholic south and had prospered in the northern provinces, especially in Amsterdam. ${ }^{6}$ There are two prime characteristics of the epithalamia they commissioned. First, the main poetic strands were taken from biblical episodes, so were very similar to what a preacher would have said at a wedding. ${ }^{7}$ These replaced the mythological and classical allusions employed by learned poets in their classical Latin encomia for powerful ruling families and monarchs on such occasions. A political message was largely absent from seventeenth-century Dutch epithalamia for the mercantile elite, the purpose of which was solely to commemorate a single, special day in the lives of the newly-weds, with content that was focused exclusively on the private circumstances of the families, friends and social circles to which the couple belonged. ${ }^{8}$ Second, some seventeenth-century Dutch epithalamia were published as separate booklets, and were by no means

4 Calvin John, The Institutes of Christian Religion, ed. and trans. T. Lane - H. Osborne (Grand Rapids: 1987) 34; see also Laqua-O'Donnell S., Women and the Counter-Reformation in Early Modern Münster (Oxford: 2014) 76-77.

5 The general guides to the Dutch epithalamic genre are Schenkeveld-van der Dussen M.A., "Poëzie als gebruiksartikel: gelegenheidsgedichten in de zeventiende eeuw", in Spies M. Berg W. van den (eds.), Historische letterkunde. Facetten van vakbeoefening (Groningen: 1984) 75-92; Bouman J., Nederlandse gelegenheidsgedichten voor 1700 in de Koninklijke Bibliotheek te 's-Gravenhage (Nieuwkoop: 1982) VII-XX; Steur A. van der, Gelegenheidsgedichten. Los verschenen gedrukte gelegenheidsgedichten op Nederlandse personen, 17e-20e eeuw (Haarlem: 2004) 5-31; Geerdink N., "The Appropriation of the Genre of Nuptial Poetry by Katharina Lescailje (1649-1711)", in Gilleir A. (ed.), Women Writing Back / Writing Women Back. Transnational Perspectives from the Late Middle Ages to the Dawn of the Modern Era (Leiden: 2010) 163-200.

6 A general introduction to the illustrations of Dutch nuptial booklets and the example of Leeuwarden is summarized in Yang J., "Starter's Contribution to a Frisian Wedding", in Boersma P. - Brand H. - Spoelstra J. (eds.), Philologia Frisica Anno 2012 (Leeuwarden: 2014) $155^{-173 .}$

7 Schenkeveld-van der Dussen M.A., "Christus, Hymenaeus of de 'teelzucht”, in Witstein S.F. Grootes E.K. (eds.), Visies op Vondel na 300 (The Hague: 1979) 11-25.

8 By contrast to the religious epithalamia for the weddings of the Dutch merchant class, Dubrow's study shows how the epithalamia for royal weddings conveyed political messages. See further, Dubrow H., A Happier Eden. The Politics of Marriage in the Stuart Epithalamium (Ithaca: 1990). 
run-of-the-mill products, but were sumptuously decorated with illustrations. ${ }^{9}$ In other words, the vogue for Dutch epithalamia gained currency as a form of bespoke luxury ephemera, and the epithalamic genre established a new readership for a highly specific combination of word and image in the early seventeenth century.

This essay demonstrates how the verbal and visual elements of Dutch illustrated epithalamia were manipulated in order to create a ritual for reinforcing a couple's pious mindset in preparation for married life, and to associate word and image in the booklets in such a way as to unify the bodies and minds of the couple into a single, God-fearing entity. The tendency of stressing biblical exemplars in poems and illustrations, rather than adopting pagan personages from the stock of poetic motifs of Latin epithalamia, is already apparent from the start of the vogue for these booklets in the $1610 .^{10}$ Later nuptial publications continued this ethic of the Protestant, Calvinist wedding, but widened the range of exemplars to include virtuous messages from contemporary illustrated books, such as didactic emblems books and songbooks. While the combination of devotional words and images was well-received by Dutch patrons and readers, the function of nuptial booklets changed from being a commemorative token of a wedding to a meditative tool used for reading religious messages, looking at images and reflecting on the admirable, pious behaviour of Christian spouses. This modification of word and image for wedding days led to an enormous in quality across the epithalamic genre in the Netherlands, especially when the different social perceptions of marriage were embedded in a Calvinist framework after the Alteration.

The aim of this essay is to differentiate the use and role of Dutch illustrated epithalamia from previous and international uses. In order to trace how the booklets could be used for nuptial prayers seeking God's guidance in a virtuous marriage, this essay first examines portrayals of Tobias and Sarah, which amplified the visual impact of the act of kneeling and praying to God before retiring to the nuptial bed. Other scenes from Dutch book illustrations will be examined in more detail in light of the moral instruction about chastity before marriage, a social code that was upheld in diverse book genres, such as emblem books, devotional songbooks and conduct books, as well as epithalamia. These two approaches will be used in the case study of an epithalamic booklet of 1637 in order to demonstrate how a very fervent Calvinist epithalamium borrowed six emblems from pictures in Jacob Cats's Proteus ofte Minne-beelden.

$9 \quad$ Yang, "Starter's Contribution" $162-169$.

10 Yang J., "Trusting Hands: The Dextrarum Iunctio in Seventeenth-Century Dutch Marriage Iconography", Dutch Crossing, on-line publication, Dor:10.108o/03096564.2016.1139786. 
Two conclusions will emerge from the case study, namely that Dutch epithalamia exchanged the voluptuous themes of traditional epithalamia for thoughtprovoking devices of word and image proclaiming standardized Calvinist values, and that they functioned as an introduction for the couple to their devotional life by guiding them in praying and meditating on the inner meaning of their marriage.

\section{A Pious Exemplar for a Wedding Night}

The style and content of seventeenth-century vernacular epithalamia did not appear out of nowhere, but played into a long tradition, namely the ancient custom of singing nuptial songs outside the bridal chamber.1 ${ }^{11}$ The classical author Menander Rhetor included exhortations and encouragement to enter the bridal chamber, describing the lovable mood of consummation: 'I am convinced the Cupids are there, their bows drawn, stringing their arrows, the tips ready smeared with the ointment of desire, whereby they will ensure that the two hearts breathe together. ${ }^{12}$ This specific advice given by epithalamists was echoed in a sixteenth-century Latin epithalamium of around 1535 by Janus Secundus: 'Soon she'll play an even more voluptuous game, / speaking sweeter endearments, / making more wanton use of her fingers, / coming up with sexier sins.'13 The dominant theme of lascivia lususque, the 'voluptuous game' of lovemaking, was the well-known topos of wedding poems, and mastery in describing the intellectual interplay between a bridal couple and their guests regarding the wedding night, as well as referring to sexual acts in the nuptial bed using teasing erotic wit, were the highlight of learned epithalamia. ${ }^{14}$ Speaking of the excessive use of poetic conceits relating to sensual, earthly

11 Wheeler A.L., "Tradition in the Epithalamium", The American Journal of Philology 51 (1930) 205-223; Wheeler A.L., Catullus and the Traditions of Ancient Poetry (Berkeley: 1934); Greene T.M., "Spenser and the Epithalamic Convention", Comparative Literature 9 (1957) 215-228; Babin M., Epithalamia. Classical Traditions and Changing Responses, Ph.D. dissertation (University of California: 1978) 172-173; Forster L., The Icy Fire. Five Studies in European Petrarchism (Cambridge: 1969); Tufte V., The Poetry of Marriage. The Epithalamium in Europe and its Development in England (Los Angeles: 1970).

12 Menander L., Menander Rhetor, trans. D.A. Russell - N.G. Wilson (Oxford: 1981) 145 .

13 Murgatroyd P., The Amatory Elegies of Johannes Secundus (Leiden: 2000) 202.

14 On Italian epithalamists who were classically inspired and who dedicated their nuptial verses to Italian court culture in Ferrara, Naples, and Milan, see further D'Elia A., "Marriage, Sexual Pleasure, and Learned Brides in the Wedding Orations of FifteenthCentury Italy”, Renaissance Quarterly 55 (2002) 379-433; D'Elia A., The Renaissance of Marriage in Fifteenth-Century Italy (Cambridge, MA - London: 2004) esp. 35-50. 
love in epithalamia, Forster says 'some safety valve becomes necessary: a genre in which, initially, the conventionally impossible surrender of the lady could be envisaged at all, and in which, furthermore, those sensual pleasures could be celebrated which the convention proscribed from treatment elsewhere', so that poets could avoid their occasional poetry being read as pornography. ${ }^{15} \mathrm{As}$ this paper will demonstrate, the modulation of sexual devices in the Dutch epithalamic publications would become far more rigorous than simply controlling the level of erotic expressions and subjects by closing the literary safety valve. ${ }^{16}$ This was a voluntary mechanism designed to spare the blushes of the happy couple.

The new convention of including occasional verses by both amateur and professional poets for marriages between members of the Amsterdam elite can be seen as the revival of the epithalamic tradition that had been transferred from Sappho to fifteenth-century Italian humanists, and definitively established as a poetical practice in Scaliger's Poetices (1561) and George Puttenham's The Arte of English Poesie (1589). ${ }^{17}$ What is often missing in Dutch vernacular epithalamia, though, is the playful erotic wit that created a mood of loving intimacy and implicitly encouraged sexual desire between the bride and groom..$^{18}$ Dutch epithalamists eschewed pompous and erudite knowledge of the art of classical poetry, and replaced the topoi of humanist motifs with biblical commonplaces of good wishes for the bridal couple, as if anticipating

15 Forster, The Icy Fire 116.

16 Schenkeveld-van der Dussen M.A., "Bruilofts- en liefdeslyriek in de 18e eeuw: de rol van de literaire conventies", De Nieuwe Taalgids 67 (1974) 449-461, esp. 451: 'Voorts dient er in het gedicht melding gemaakt te worden van 'lascivia lususque'; men wijst op de vrees van de bruid voor de komende strijd, maar ook op de komende overwinning; men spreekt wensen uit voor een spoedig nageslacht. [...] Kortom, het is duidelijk dat sex volgens de theorie in een huwelijksgedicht thuishoort - al wijst Scaliger wat plichtmatig op de gevaren van te grote loszinnigheid - en uit de practijk blijkt dat deze voorschriften ook gevolgd werden'.

17 Scaliger helped establish the guidelines for writing occasional poetry because he made it easier for poets to deal with the subject matter of the epithalamic genre by summarizing the six loci communes: the groom's desire for the bride, praise of the couple, good wishes, an allusion to lascivia lususque, hopes for fruitfulness in offspring and fortune, and an appeal to the guests to depart and let the couple retire to the nuptial bed. See further, Scaliger Julius Caesar, Poetices libri septem / Sieben Bücher über die Dichtkunst, ed. and trans. M. Fuhrmann - L. Deitz, 6 vols. (Stuttgart: 1994-2003) vol. 3, 64, 66. Puttemham also included the genre of epithalamia in his treatise, chapter 26, "The Maner of Reioysings at Marriages and Weddings": Puttenham George, The Arte of English Poesie (London, Richard Field: 1589; facs. of the first edition, Menston: 1968) 64-68.

18 Schenkeveld-van der Dussen M.A., "Bruiloftsdichten in de tale Kanaäns: het probleem van de onverstaanbaarheid", De Nieuwe Taalgids 75 (1982) 50-6o; Schenkeveld-van der Dussen, "Christus, Hymenaeus". 
a national cliché of following a modest, God-fearing Calvinist lifestyle. In addition to the religious emphasis in epithalamia, the Dutch saw an enhanced role for illustration based on the classical idea of the sister arts by combining the verses with images. Popular poets and skilled artists joined forces to turn the booklets into something more than fleeting accompaniments to a social occasion, and contributed to the sophistication of their audience by varying the delights conveyed by word and image. ${ }^{19}$

The contents of the verses therefore had a major impact on the iconographic programmes of illustrations on the title pages, which served to announce the contents of the text itself. If the poet were to follow the formula of classical epithalamia, referring to lascivia lususque alone, the accompanying illustrations would have been totally out of keeping with the ethos of a Christian wedding. In Dutch epithalamic booklets the religious messages corresponded to the adornments of the frontispieces, which encapsulated biblical episodes in order to sermonize on virtuous Christian marriage.

This is in marked contrast to the epithalamic booklet for the wedding of Rombout Jacobsz the Younger and Hillegonda van Baesdorp, designed by Claes Jansz Visscher, which illustrates how a pictura of a love emblem - les deux sont un', with a Cupid grafting two different trees together in order to represent the epigram of 'the two are one' - could be given a religious significance by featuring other biblical examples, such as the first biblical union of Adam and Eve bonded by God's will, as represented by the vertical tetragrammaton for Jehovah beside the standing Eve. ${ }^{20}$ [Fig. 9.1] The four scenes in the corners are the meeting of Isaac and Rebecca from Genesis 24; Christ's first miracle at the Wedding at Cana from John 1; the nuptials of Tobias and Sara from Tobit 8; and a family saying grace from Psalm 128, with its metaphors of the wife as a fruitful vine and children as olive plants. ${ }^{21}$ This illustrative repertoire highlights the

19 Yang, "Starter's Contribution".

20 The early example of 'Les deux sont un' can be found in Heinsius Daniël, Quaeris quid sit Amor (Amsterdam, Herman de Buck: 16o1) fols. F4v-Gir: "Les deux sont un [19]". Replacing God's presence with the tetragrammaton in the scene of Adam and Eve was in line with the Calvinist dogma of not depicting God in human form. Prints designed by Claes Jansz Visscher have been studied in relation to his fervent beliefs as an ultraorthodox Calvinist expressed in his radical broadsheets denouncing Remonstrants and Catholics. His purpose was clearly to enshrine Calvinist views about nuptial imagery. On Visscher's religious position, see Orenstein N. - Luijten G. - Schuckman Ch. - Leeflang H., "Print Publishers in the Netherlands 1580-1620", in Luijten G. - Suchtelen A. van (eds.), Dawn of the Golden Age. Northern Netherlandish art, 1580-1620, exh. cat., Rijksmuseum (Amsterdam: 1993) 167-200, esp. 189-195.

21 On the subject of the family saying grace executed by Dutch graphic artists, such as De Gheyn II, Crispijn van de Passe, Pieter Serwouters, and Visscher between 1595 and 1610, 


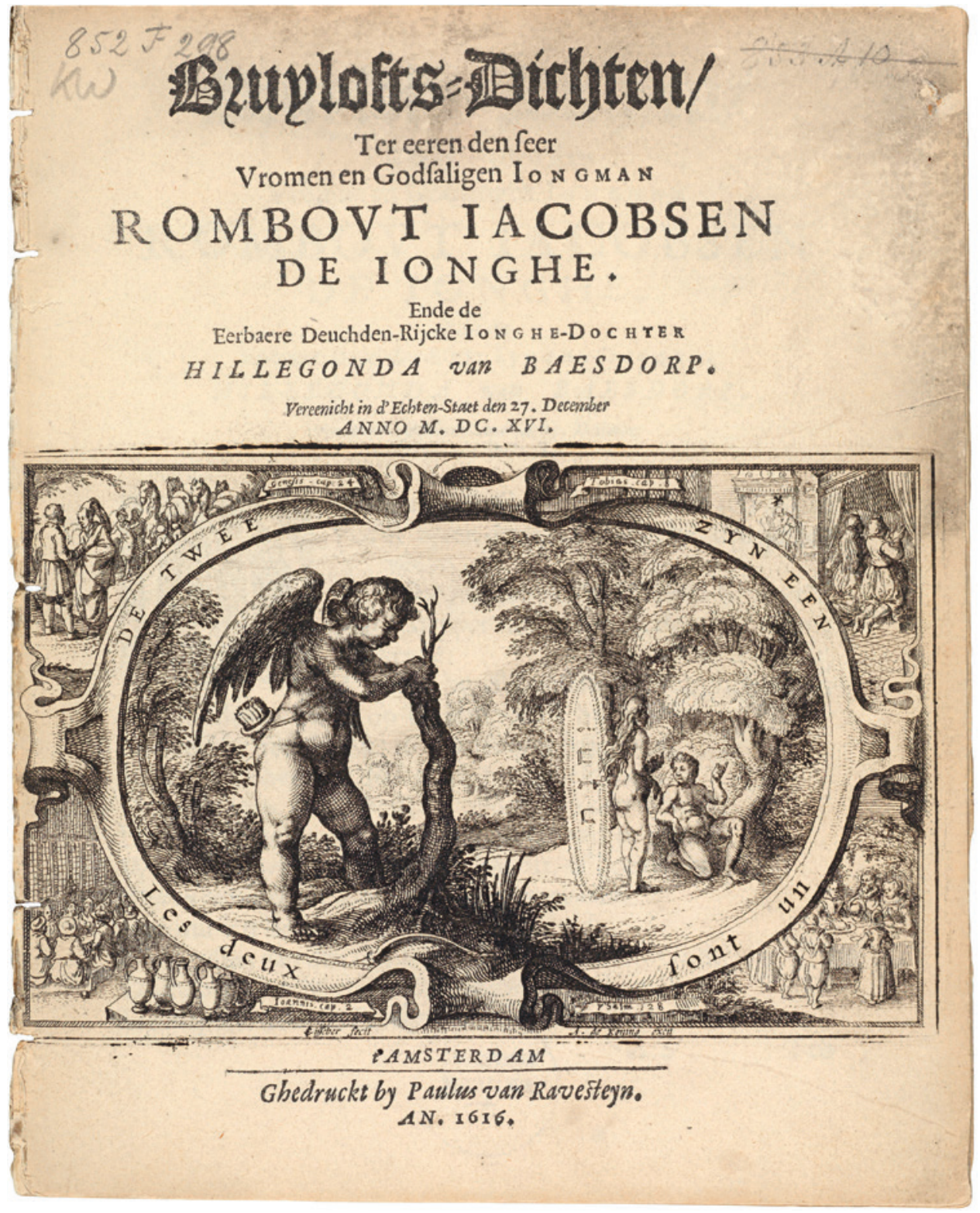

FIGURE 9.1 Claes Jansz Visscher, frontispiece of Bruylofts-dichten [...] Rombovt Iacobsen de ionghe [...] Hillegonda van Baesdorp [...] (Amsterdam, Paulus van Ravesteyn: 1616). The Hague, National Library of the Netherlands 
standard epithalamic usage that was highly regarded as a credit to the author, the patron and, by extension, to the audience too. Most Dutch epithalamic title pages did not embody the poetic motifs of carnal desire and the sexual connotations of classical epithalamia, which would have been abhorrent lustful and unchaste. ${ }^{22}$

Among these repertoires, the wedding night of Tobias and Sarah made it possible to portray the religiously sensitive issue of a married couple becoming one flesh. Tobias, who was Sarah's eighth groom, was under the protection of the archangel Raphael, since her previous seven husbands had been killed by the demon Asmodeus before they could consummate their marriage. Raphael told Tobias to burn the heart and liver of a fish, the smell of which would drive out the devil. Visscher shows them kneeling in prayer, with the demon in the fireplace in the background on the left, reminding viewers of Tobit's sincere prayer that he might suppress lustful desire and obey God.

There is a very similar depiction of Tobias and Sarah praying in Maarten van Heemskerck's two print series of the Story of Tobias (ca. 1548 and 1556) [Figs. 2 and 3]. Visscher must have known those sixteenth-century prints and could have borrowed the couple's pose in order to emphasize the act of prayer. Van Heemskerck's prints and Visscher's illustration all portray the biblical couple praying in front of their nuptial bed, setting a visual example of the importance of piety before consummation. The act of prayer is totally at odds with the classical epithalamists' emphasis on the delights of lascivia lususque, which formed the mainspring of conventional Dutch vernacular epithalamia.

Visscher's image of the wedding night would have been chosen for the opportunity it gave to stress the importance of religious rather than physical

see Thiel P.J.J. van, "Poor Parents, Rich Children and Family Saying Grace", Simiolus 17 (1987) 90-149, esp. 128-141; Jongh E. de, "Grape Symbolism in Paintings of the 16th and 17th Centuries”, Simiolus 7 (1974) 166-180, esp. 189-190; Jongh E. de - Luijten G. (eds.), Mirror of Everyday life. Genreprints in the Netherlands 1550-1700, exh. cat., Rijksmuseum (Amsterdam: 1997) 124-128; Luijten - Suchtelen, Dawn of the Golden Age 628-629; Franits W., "The Family Saying Grace: A Theme in Dutch Art of the Seventeenth Century", Simiolus 16 (1986) 36-49.

22 The anonymous poet, who signed his works with the motto 'Winnen maeckt vreucht' (Winning brings joy), was obviously stressing the devotional nature of the wedding poem, placing God's instruction at the heart of it: 'The chastity that exists in the chaste mind, I believe,/ Be it in or outside Marriage, the pious is already pure./ Blessed by the Lord by the marital state,/ God wishes that man will spread his seed here' ('De kuyscheyt die bestaet int kuysch gemoedt, ick meyn,/ 'T zy in oft uyt de Echt, den vromen ist al reyn./ Door d'Houwelycken staet gesegent van den Heere,/ Wil Gode dat den mensch syn zaet hier sal vermeeren.'). Bruylofts-dichten, Rombovt Iacobsen de ionghe ende Hillegonda van Baesdorp (Amsterdam, Paulus van Ravensteyn: 1616) fol. A2v. 


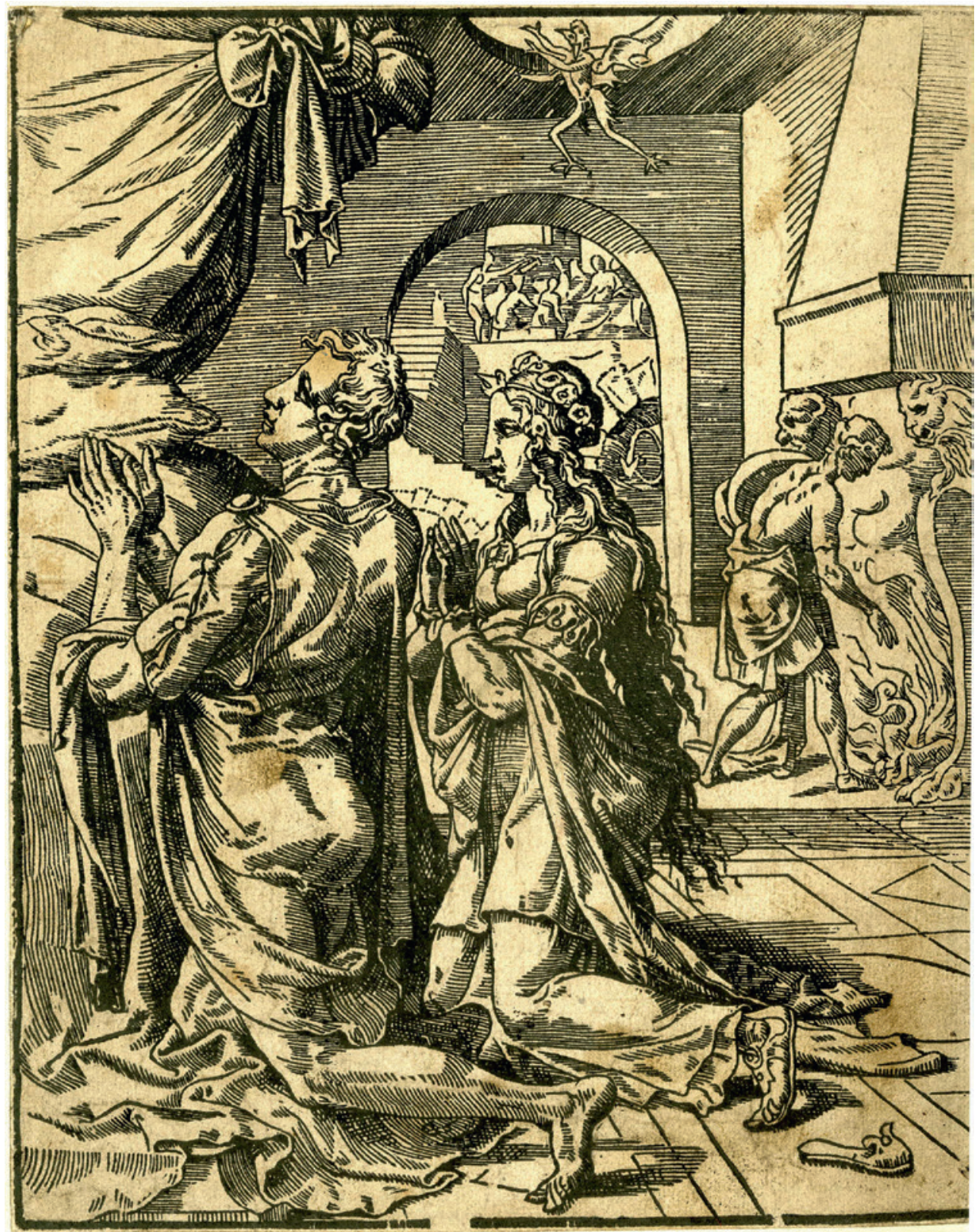

FIGURE 9.2 After Maarten van Heemskerck, "The Wedding Night of Tobias and Sarah", from the Story of Tobias (ca. 1550). Woodcut, $19 \times 24.2 \mathrm{~cm}$. London, The British Museum (C) TRUSTEES OF THE BRITISH MUSEUM 


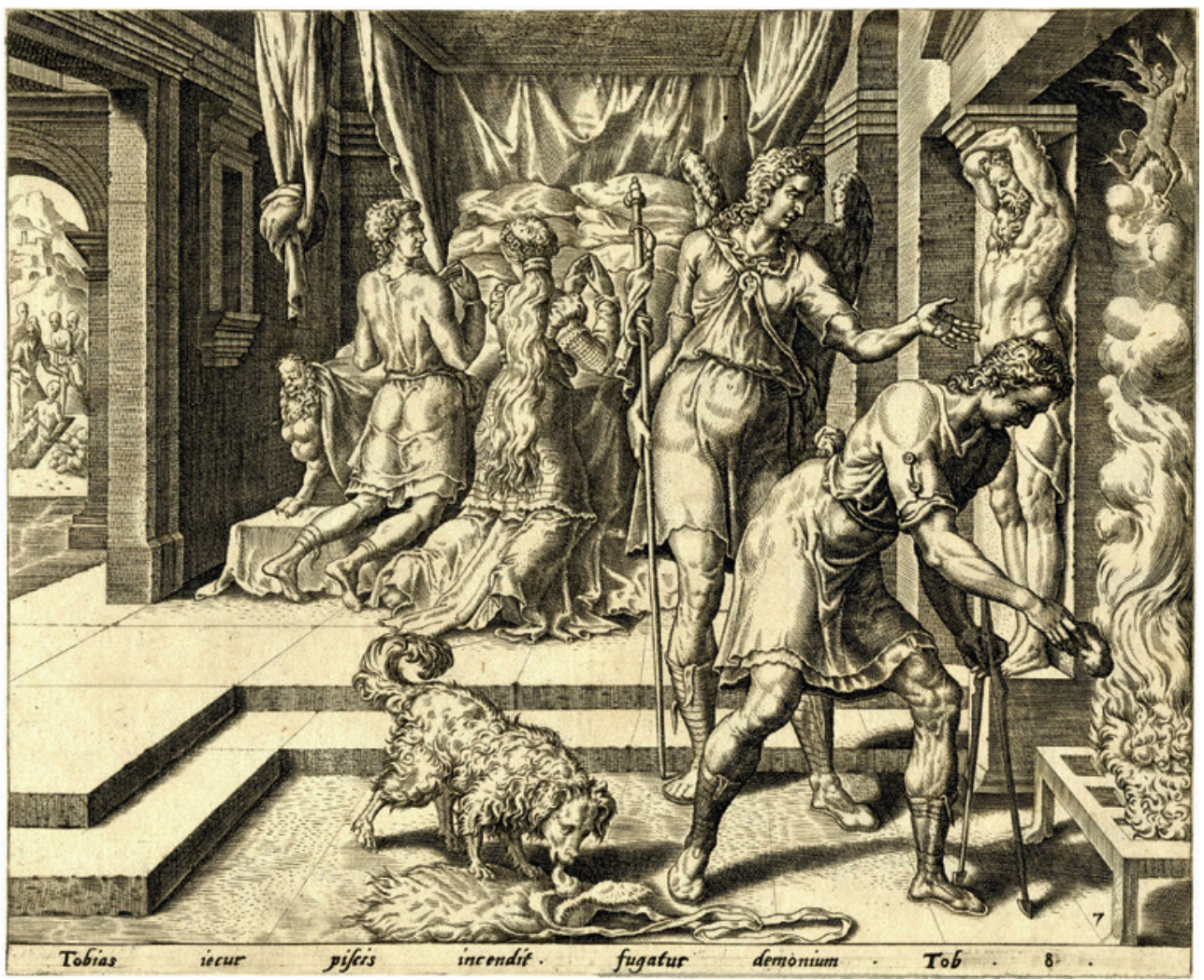

FIGURE 9.3 After Maarten van Heemskerck, "The Wedding Night of Tobias and Sarah", from the Story of Tobias (1556). Engraving, $24.6 \times 20 \mathrm{~cm}$. London, The British Museum (C) TRUSTEES OF THE BRITISH MUSEUM

consummation, with the accompanying illustrations functioning as sermonizing images, and their influence is very apparent in later paintings by Nicolaes Knupfer and Jan Steen, in which the couple are also kneeling by their bed before retiring. ${ }^{23}$ [Fig. 9.4] The object was to stress the intensely religious ritual of the wedding night, as illustrated by the bride and groom's prayer, which marked the start of their devotional life together. Jan Steen's painting was cut into two parts, why or by whom is not known, but the praying couple were clearly seen as a distinct and separate motif, and may have been removed so as to isolate and stress the importance of couples praying at their marriage bed. ${ }^{24}$

23 Two versions of the Wedding Night of Tobias and Sarah are included in the monograph: Saxton J., Nicolaus Knupfer. An Original Artist (Doornspijk: 2005) 113-115.

24 Westermann M., The Amusement of Jan Steen (Zwolle: 1997) 54. 


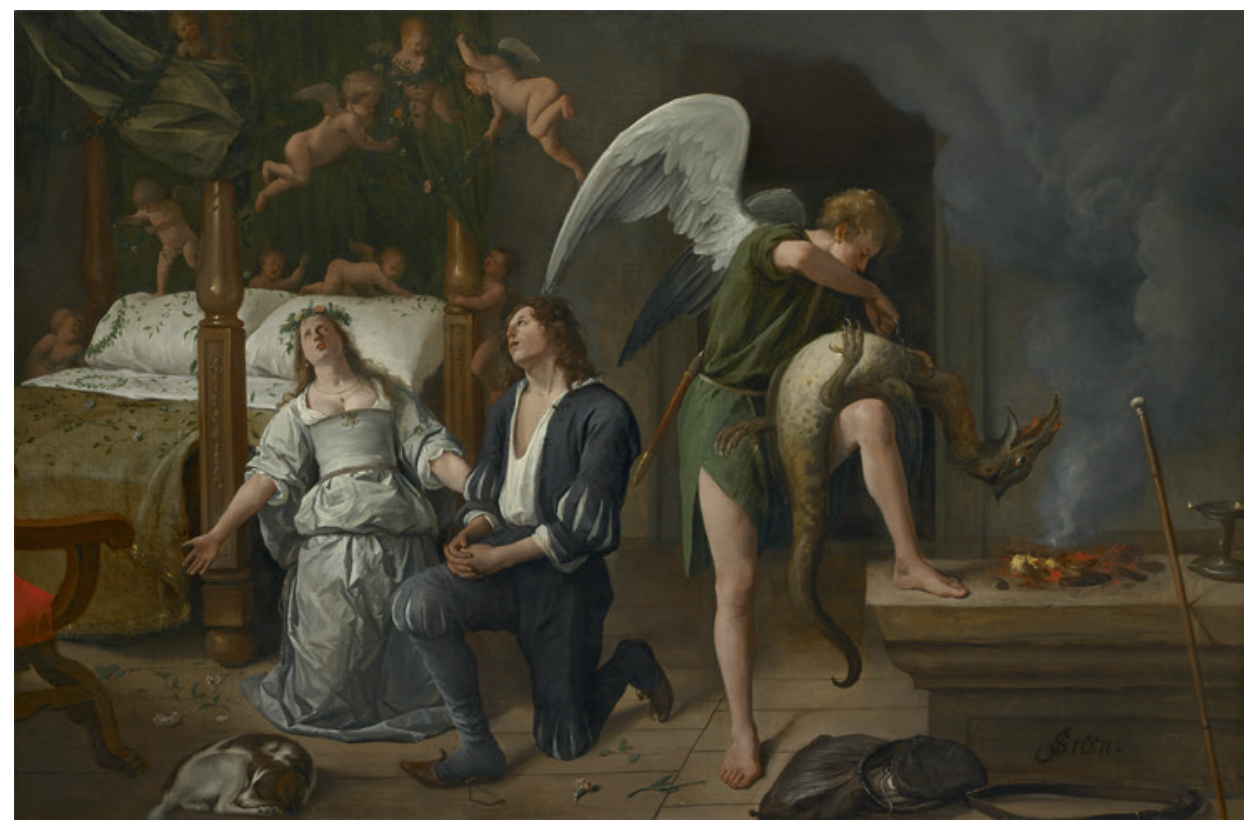

FIGURE 9.4 Jan Steen, "The Wedding Night of Tobias and Sarah" (ca. 166o). Oil on canvas, $81 \times 123 \mathrm{~cm}$. The Hague, Museum Bredius

As far as the subject of prayers at the nuptial bed is concerned, the wedding night of Tobias and Sarah is very reminiscent of Roman Catholic marital culture. The nights of Tobias - a period of sexual abstinence - were recommended by Catholic preachers to strengthen the spiritual affinity of the couple before nuptial intercourse. Newly-weds were counselled, out of respect for the nuptial blessing, to defer consummation for three nights, or at least until after the wedding night, devoting themselves to prayer instead. ${ }^{25}$ This ecclesiastical rite that flourished in the Middle Ages would not have been a favoured topic for Reformed churches. For a start, Luther did not turn Tobias's abstinence into a general rule, with the result that the episode of the story of Tobias disappeared from Lutheran preaching. ${ }^{26}$ By contrast, he used other biblical examples in preaching about weddings, such as Isaac and Rebecca, David and Abigail, and Ahasuerus and Esther. However, the wedding night of Tobias and Sarah was still emphasized by the Catholic priest and Limburg writer Franciscus Agricola

25 Hall E., The Arnolfini Betrothal. Medieval Marriage and the Enigma of Van Eyck's Double Portrait (Berkeley: 1994) 23.

26 Brown C.B., "The Reformation of Marriage in Lutheran Wedding-Preaching", Seminary Ridge Review 15, 2 (2013) 1-25, esp. 16. 
(ca.1545/50-1620), who was still placing Tobias and Sarah at the core of Catholic nuptial advice in the early seventeenth century in order to highlight marriage as the sacrament of holy matrimony. ${ }^{27}$ It is clear, though, that the revival of the episode was more related to the function of the wedding booklet. By showing the bridal prayers, the proper use of the wedding booklet was limited to a devotional purpose, unlike classical epithalamia.

The use of the subject of Tobias and Sarah was therefore a poetic device that invited emulation and promoted the honourable joy of the married state in the chaste marriage bed. The main concern of seventeenth-century Dutch religious epithalamists was to make Christ the witness of the marriage (Wedding at Cana) and to instruct the bridal couple that Christ is the only sponsor of a chaste Christian marriage, and that therefore the couple must offer up a preparatory prayer before consummating their union. The arousal of inner, more refined feelings about the wedding night in the context of prayer and meditation on biblical precepts was the important point in early seventeenth-century Dutch epithalamia, and the scene of the prayers before the nuptial bed is thus a symbolic and essential rite for the bridal couple. ${ }^{28}$

\section{$2 \quad$ Propriety on the Wedding Night}

Other Dutch religious writers, including epithalamists, highlighted the importance of the way newly-weds entered into their devotional life together. The code of conduct for wedding nights was also expounded in Dutch literature, such as moralistic emblem books, in which instructions on how to prepare for the devotional wedding night are conveyed through words and images, much like illustrated epithalamia. For instance, in his Emblemata of sinne-werck of 1624, the Zeeland author Johan de Brune (1588-1658) foregrounded the

27 Agricola Franciscus, Biblischer Ehespiegel. In Siben Catholischen Ehe- oder Braut-Predigen verfasset (Cologne, Bernhard Woter: 1599) 75-76; Dressen-Coenders L., Het verbond van heks en duivel. Een waandenkbeeld aan het begin van de moderne tijd als symptoom van een veranderende situatie van de vrouw en als middel tot hervorming der zeden (Baarn: 1983) 176-177.

28 The virtue of having a pious wedding night had already been emphasized by Erasmus in his Christiani Matrimonii Institutio of 1526 : 'Let us make Christ the witness and sponsor of Christian marriage, so that no impurity may soil relations with a spouse; let the husband persuade his wife, through God's decrees and laws, to do willingly and joyfully what she has learned is pleasing to the Lord. Let both partners first pray to him in unison to bestow his favour on their marriage; after prayer, let them engage in pious conversation. Finally, let their lovemaking be modest and virtuous, the opposite of fornication and rape'. English translation from Rummel E., Erasmus on Women (Toronto: 1996) 101. 
importance of piety and lifelong marital devotion that should start from the bridal couple's first night together. ${ }^{29}$ The pictura of an emblem entitled 'Het Houw'licks bed zy onbesmet' ('Let the marital bed be unsullied') illustrates a familiar contemporary setting, unlike Visscher's biblical adoption of the kneeling Tobias and Sarah. [Fig. 9.5] The picturae for this emblem book were designed by Adriaen van de Venne (1589-1662), who wrote a versified description of how his illustrations function in his Zeeusche Mey-clacht: 'All that a great poet knows how to bring forth, / All that is unseen that a great mind can see, / The art of painting shows as if it really happened. ${ }^{30}$ The addition of such visual reality to strengthen the verbal message is the key to the Emblemata, creating a fresh channel of visual communication to the readers. ${ }^{31}$

In the emblem picture, a fully dressed bride holding a pomander is seated next to the nuptial bed, its pillows adorned with the couple's crowns and the floor strewn with flowers. The four women standing beside her are about to retire for the night, establishing that the scene is set just before the departure for the nuptial bed, when the women would be advising the bride on how to conduct herself on this important night. The old lady, for example, gives the bride a good talking-to about the night, which fits the content of the subscriptio:

When you, bound two-in-one by wedlock's bond, In that which leads your fiery heart to sacred water, Before savouring the fruit of marriage Vow to yourself chastity eternal.

No trough of foul lust is the marital bed,

But there, those who use it in a seemly manner shall remain maidenly.

When, both bedecked with an honourable blush, you go to take your rest there,

Be sure, both together, to commit no impropriety. ${ }^{32}$

29 Porteman K., "Johan de Brunes emblematische essays", in Verkruijsse P.J. (ed.), Johan de Brune de Oude (1588-1658). Een Zeeuws literator en staatsman uit de zeventiende eeuw (Middelburg: 1990) 108-119; Kolfin E., The Young Gentry at Play. Northern Netherlandish Scenes of Merry Companies 1610-1645 (Leiden: 2005) 232-234.

$30 \quad$ Venne Adriaen van de, Zeeusche Nachtegael (Middelburg, Jan van de Venne: 1623) 64: 'Al wat een Cunst-Poët te voorschyn weet te halen,/ Al wat een groot verstant onsienelicken siet,/ Dat thoont de Schilder-const al offet waer geshiet'.

31 See further on Adriaen van de Venne as illustrator, Bol L.J., Adriaen Pietersz. van de Venne. Painter and Draughtsman (Doornspijk: 1989) 112-127.

32 Brune Johan de, Emblemata of Zinne-werck (Amsterdam, Jan Evertsen Kloppenburch: 1624) 9: 'Als ghy, twee-eenigh, zijt, door echten band, gesloten/ In 't geen uw brandigh hert tot heyligh water leyd,/ Al-eer ghy noch de vrucht des houw'licks hebt genoten,/ Doe by $u$ zelf beloft van eeuwigh eerbaerheyd./ Het houw'licks bed en is geen goot' van vuyle 
E M B L E M T A

II.

Het Houw'licks bed zy onbefmet.

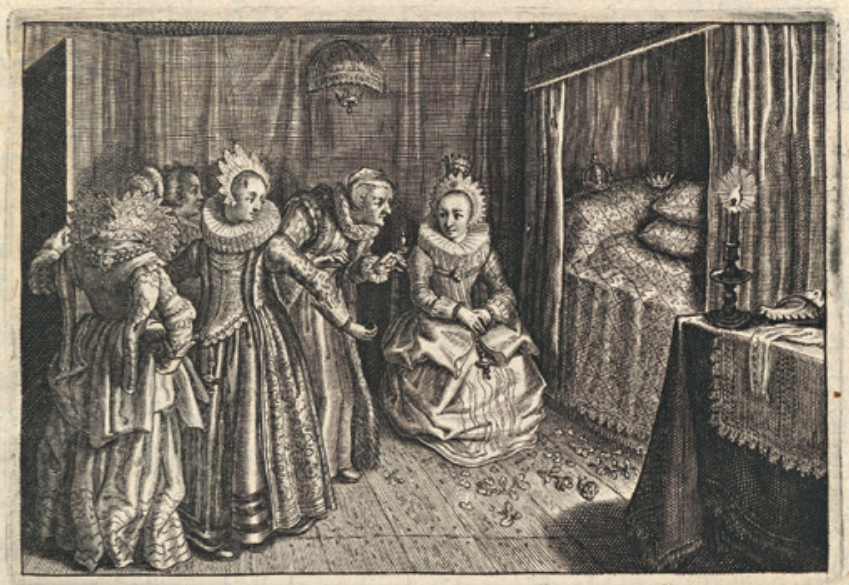

A ls gby,twee-eenigh,zijt,door ecbten band,gefloten A In'tgeen uw brandigh bert tot beylighwater leyd, Al-eer gby nocb de vrucbi des boww'licks bebt genoten,

Doe by uzelf belof a van eeuwigh eerbaerbeyd.

Het boun'licks bed en is geen goot' van vuyle lusten,

Maer daer, die't wel gebruyckt, elckeen in maegh. dom blijft.

Als ghy dan, beyd' bedeckt met eerbaer root, gaet ruften,

Zie dat gby dan te zaem geen over-pel bedrijft.

$\mathcal{B}$

Wte

FIGURE 9.5 Adriaen van de Venne, engraving in Johan de Brune, Emblemata of Zinne-werck (Amsterdam, Jan Evertsen Kloppenburch: 1624), "Het Houw'licks bed zy onbesmet" 9. The Hague, National Library of the Netherlands. 
Emblems of this kind are thus closely related to epithalamia in their insistence on seemliness and the purity of the nuptial bed, as if echoing the line from Tobit 8:7: 'O Lord, I take not this my sister for lust but uprightly'. Dutch writers accordingly put Christian piety above merry verses when commemorating the wedding night, and the theme of the marriage bed was not a topos for lascivia lususque, which was the main concept of traditional epithalamia, but a medium for providing the bridal couple with spiritual guidance. It can be said, then, that a certain restraint was exercised when dealing with nuptial topics, stressing the pure and honourable bond between a man and a woman, which had its parallel in the devout approach adopted in Dutch epithalamia.

The extremely popular publication of 1625 entitled Houwelick, by Jacob Cats (1577-1660), a famous seventeenth-century poet and moralist, and the advocate of Christian marriage, also focused very firmly on providing maidens with moral instructions on how to prepare for marriage. ${ }^{33}$ First and foremost, the chapter titled 'Bruyt' (Bride) highlights how respectable Protestants wished newly-weds the joys of a chaste Christian marriage and advocated the creation of a devotional atmosphere before becoming one flesh. Cats's instructions about the wedding day cover various topics, such as the behaviour of the wedding guests, the bride and groom's mental preparation, orchestrating the mood of the wedding banquet, the symbolic meaning of the bride's crown, conduct at the nuptial bed, and pious conversation between bride and groom. ${ }^{34}$ There were also taboos like drinking too much wine, jolly entertainments, and any kind of disruption that would disturb reverent minds; for example, on the jostling of wedding guests when the bride retires to the nuptial bed, Cats writes: 'That here no wanton moppet may create turmoil or speak impudently at the door. No gamester, no clamour, no song shall hinder the bride and her attendants as she prays within'. ${ }^{35}$ Reciting frivolous or voluptuous epithalamic verses before the couple retired to their nuptial chamber would therefore have been considered utterly inappropriate due to their filthy language and slyly lewd allusions. By the same token, the images that accompanied

lusten,/ Maer daer, die 't wel gebruyckt, elck een in maeghdom blijft./ Als ghy dan, beyd' bedeckt met eerbaer root, gaet rusten,/ Zie dat ghy dan te zaem geen over-spel bedrijft'.

33 Franits W., Paragons of Virtue. Women and Domesticity in Seventeenth-Century Dutch Art (Cambridge - New York: 1993) 5-9, 67-68.

34 Cats Jacob, Houwelick (Middelburg, Jan van de Venne: 1625), the third part "Bruyt" fols. $29 \mathrm{v}-33 \mathrm{v}$.

35 Cats, Houwelick, the third part "Bruyt" fol. $3^{2 v}$ : 'Dat hier geen dertel wicht, met onbeschofte streken,/ En maecke voor de deur te tieren, of te spreken;/ Geen speelman, geen geroup, geen sang en doe belet;/ De bruyt, en haer ghevolch, doet binnen haer gebet'. 
the nuptial verses had to befit this standard, arousing only pious affection for the couple's future.

Cats's propaganda on the characteristics, virtues and duties of a Dutch burgher household on its bedrock of piety was succeeded in a later publication, Petrus Wittewrongel's Oeconomia Christiana ofte Christelicke huyshoudinghe (Christian Domestic Economy, or The Christian Household). ${ }^{36}$ Like Cats's warning against secular and lustful entertainment on the wedding day, Wittewrongel stresses that the virtuous bridal couple should set up their wedding night in spiritual terms as follows: 'The marital bed must in no way be befouled by carnal excesses, licentious unchaste discourses, impure and salacious licentiousness; the marital bed must quench the lusts, not inflame them.' ${ }^{37}$ Visscher's depiction eliminated any suggestion of lust or physical intimacy, and in this he was followed by De Brune, Cats and Wittewrongel, all of whom insisted that the marriage bed was not an excuse for lascivia lususque, but was to be used solely for devout consummation.

\section{3}

\section{Cautionary Images from Cats's Emblem Book}

As can be seen from the Dutch religious authors' determined attempts to protect the nuptial bed from voluptuous amusement and to keep it honourable and chaste, their attitude was fervent in the extreme and went far beyond merely controlling the level of erotic jokes with the epithalamists' safety valve. The words and images of Dutch epithalamia could aid contemplation of the pious rite of marriage, not only for the bridal couple but for their guests as well. ${ }^{38} \mathrm{~A}$ fine example of this puristic Protestant attitude is found in the ephemeral booklet of 1637 for the wedding of Samuel Hespel, a gold thread drawer of Amsterdam, and Clara van Belle. The epithalamium was written by Pieter van Belle, the bride's elder brother. He was a baker and amateur poet who mainly composed religious sonnets and occasional poetry for his relatives' weddings and funerals, showing that he, at least, was keen on perpetuating a family tradition.

\footnotetext{
$36 \quad$ Franits, Paragons 109.

37 Wittewrongel Petrus, Oeconomia Christiana ofte Christelicke huyshoudinghe (Amsterdam, voor de weduwe van Marten Jansz Brant en Abraham van den Burgh: 1655) vol. 1, 142: 'Het Houwelicks-bedde, en behoort geensins/ door vleeschelicke excessen, lichtveerdige onkuysche redenen, onreyne ende geyle lichtveerdigheden verontreynight te worden; het Houwelicks bedde moet de lusten uyt-blusschen, niet ontsteecken'.

$38 \quad$ Kolfin, Young Gentry 229-235.
} 

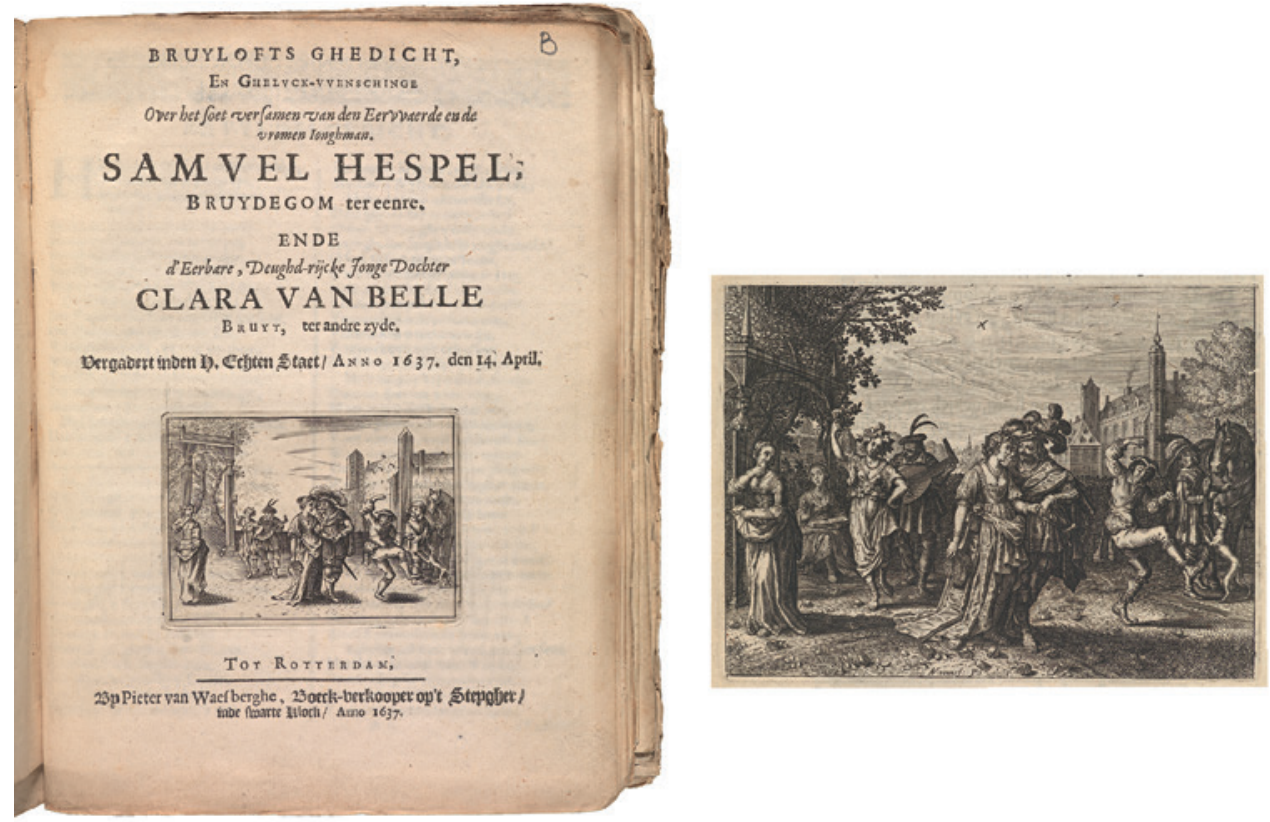

FIGURE 9.6 (Left) Anonymous, frontispiece of Pieter van Belle, Bruylofts ghedicht en ghelvckvvenschinge over het soet versamen van [...]. Samvel Hespel [...] Clara van Belle (Rotterdam, Pieter van Waesberge: 1637). The Hague, National Library of the Netherlands

(Right) Adriaen van de Venne, engraving in Jacob Cats, Self-Stryt (Middelburg, Jan van de Venne: 1620) 50. The Hague, National Library of the Netherlands

The booklet was an amalgam of personal messages to the bridal couple in the form of poems, and an anonymous artist's copies of well-known illustrations from two of Jacob Cats's books adapted to suit the purpose of a wedding booklet. They are the frontispiece from Self-Stryt of 1620 [Fig. 9.6], and six emblems from the illustrations of Proteus ofte Minne-beelden, which was originally designed by Adriaen van de Venne and issued by the same publisher as the 1637 booklet [Figs. 9.7 and 9.8]. The publisher provides one of the clues as to why these images were attached to the booklet. He was Pieter van Waesberge, who had published Zacharias Heyns's Emblemata: Emblems Chrestienes et Morales, Sinne-Beelden enz. in 1625, and in 1627 issued Cats's Proteus ofte Minne-beelden. ${ }^{39}$ It is true that the picturae for the emblems in the latter publication are not identical to the illustrations in the wedding booklet, but the anonymous artist hired by Van Waesberge obviously copied directly

39 Ledeboer A., Het geslacht van Waesberghe. Eene bijdrage tot de geschiedenis der boekdrukkunst en van den boekhandel in Nederland (The Hague: 1859) 80-81. 

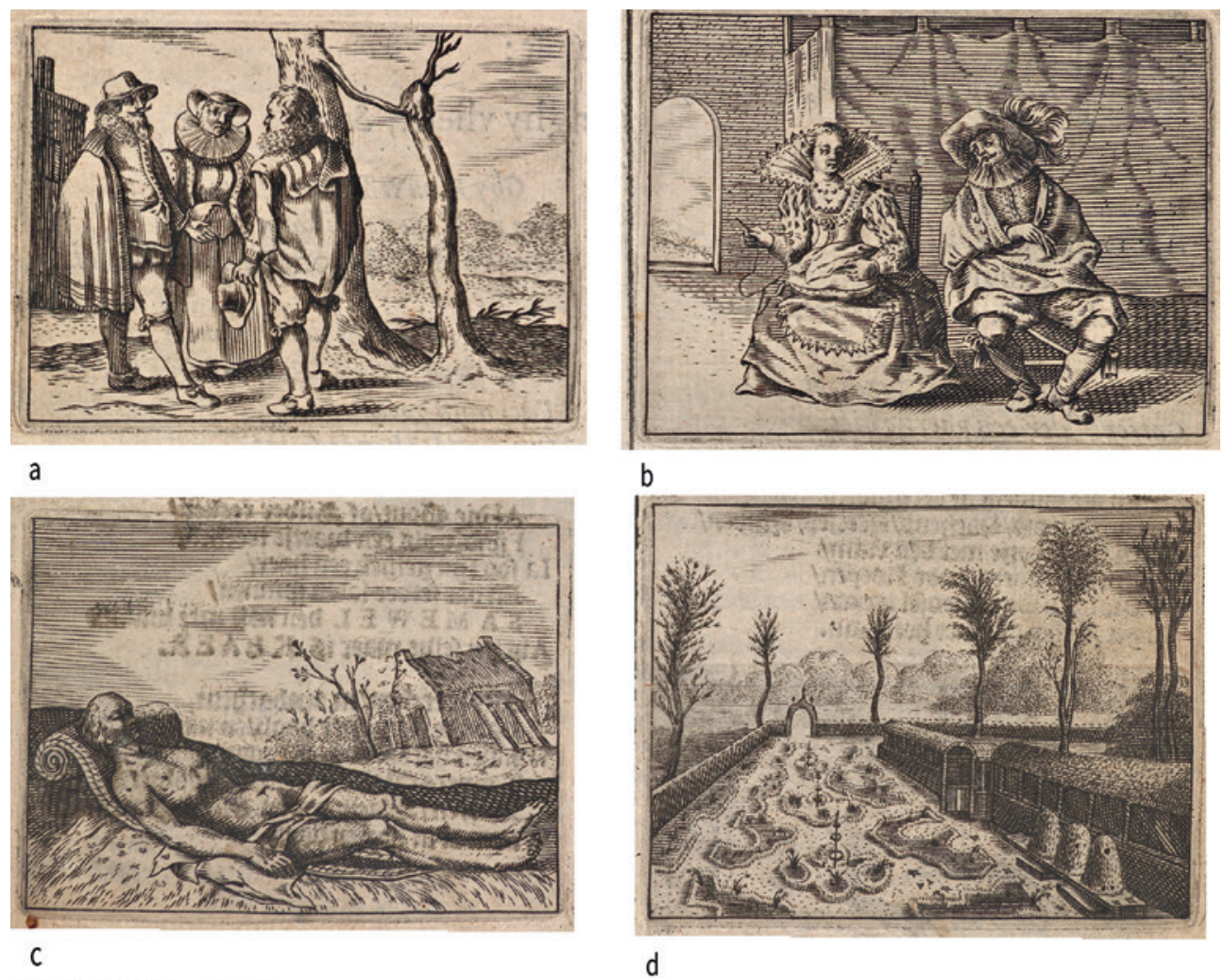

C

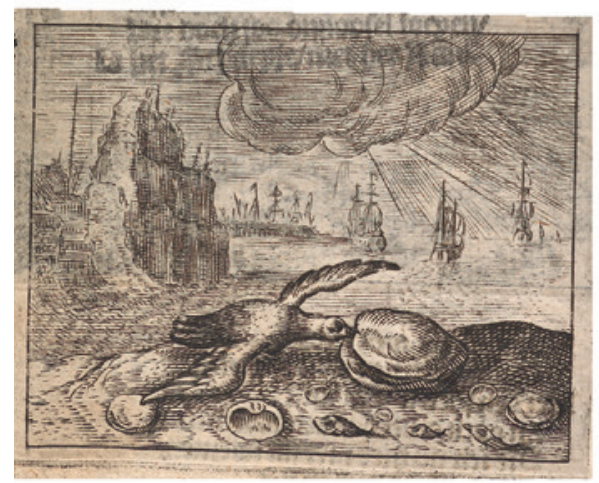

e

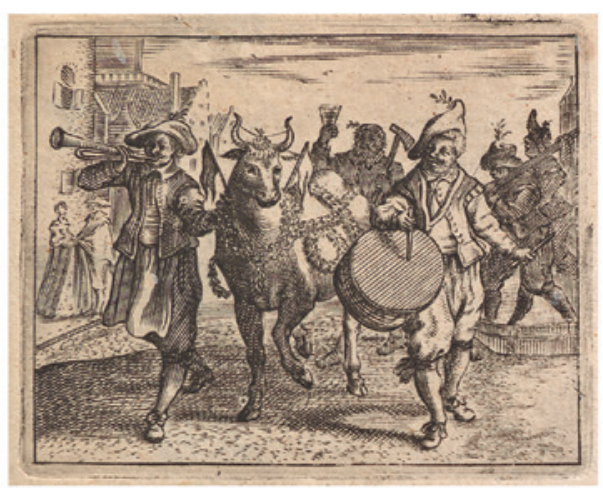

FIGURE 9.7 (a)-(f) Anonymous, six engravings in Pieter van Belle, Bruylofts ghedicht en ghelvck-vvenschinge over het soet versamen van [...]. Samvel Hespel [...] Clara van Belle (Rotterdam, Pieter van Waesberge: 1637) A4v-A6r. The Hague, National Library of the Netherlands 


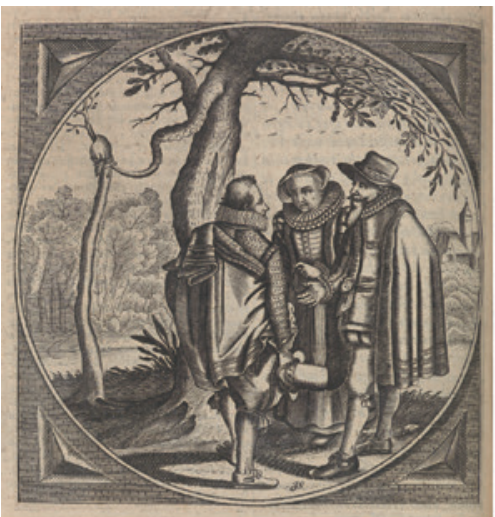

a

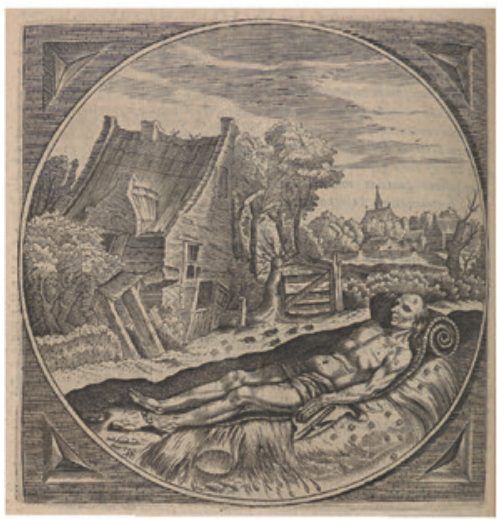

c

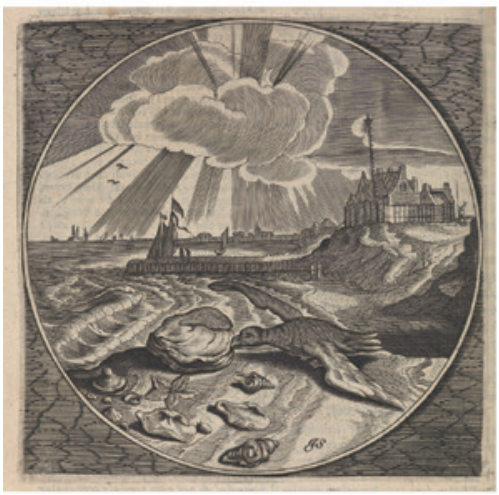

e

FIGURE 9.8 After Adriaen van de Venne, six emblem picturae in Jacob Cats, Sinne- en

Minnebeelden (Rotterdam, Pieter van Waesberge: 1627). (a) "Iam plenis nubilis annis. [45]" 226; (b) "Post tristia dulcor. [38]" 224; (c) "Nemo dolens patet libidini. [51]" 302; (d) "Turpe senilis amor. [33]" 194; (e) "Qui captat, capitur. [25]" 146; (f) "Quod iuvat exiguum est. [19]" 110. The Hague, National Library of the Netherlands

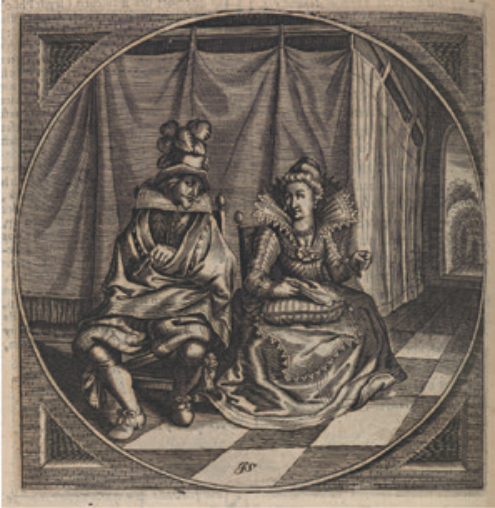

b

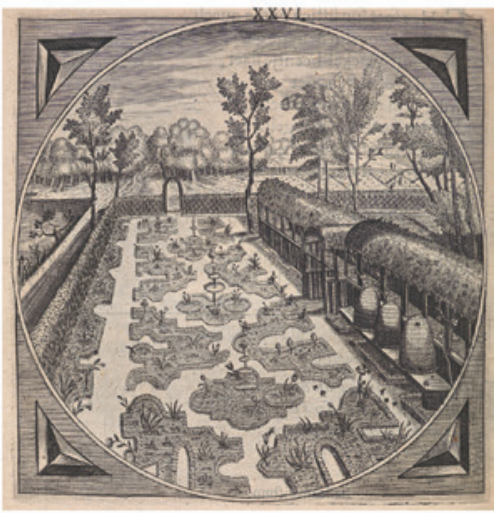

d

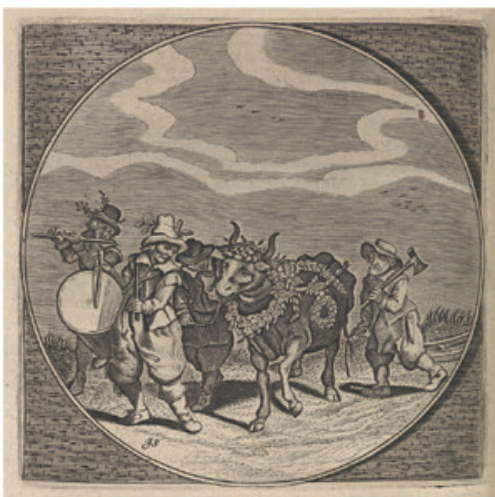


from them in order to adapt the meaning of the images for the purpose of the nuptial ephemera at the family banquet.

The title page stands in stark contrast to the six emblematic illustrations in that it depicts the bad example of light-hearted festivities and very physical pleasures, whereas the contents of the booklet, both verbal and visual, are very pious and edifying. Cats's Self-Stryt deals with the age-old inner struggle between the flesh and the spirit, similar to the homily in his later work, the Houwelick, in which he declares that newly married couples should devote their wedding night to being pious and devout. One might doubt that the title page has religious connotations, since it appears to depict merely a jolly theatrical scene peopled by allegorical figures. As Kolfin has pointed out, Van de Venne's illustration is a classic merry company scene portraying 'the marriage of Youth and Joy' in the centre. ${ }^{40} \mathrm{On}$ the left, the activities of eating, drinking, making music and dancing are symbolized by the woman eating an apple, the seated woman with the songbook, the dancing woman with a wineglass, and the masked lutenist. On the right, a merry jester is dancing beside a man standing by a horse, while a dog jumps up at him. The reason for linking this satirical image to a wedding booklet was not to evoke the festive mood of a wedding day along the lines of a theatrical interlude, but to show the other side of the coin, namely how these negative adjuncts of a wedding day should be avoided, just as Cats warned against impious and imprudent behaviour at the feast.

This is exactly the same as the original intention of adding illustrations to the edifying texts, as can be seen from the preface of Cats's Silenus Alcibiades, sive Proteus: 'They are mute but nevertheless speaking images, pretty affairs, and yet not without weight, / ridiculous things though not without wisdom:/ Into which (I say) one generally always reads/ more than there is: and thinks still more than one sees' ${ }^{41}$ Cats's emblem book differed from other Petrarchan amorous love emblems, since didactic and religious teachings about Christian virtues like humility, cautiousness, moderation, wisdom, and steadfastness, were upheld as essential. ${ }^{42}$ His readers were reminded of the transience of

$40 \quad$ Kolfin, Young Gentry 217.

41 Cats Jacob, Silenus Alcibiades, sive Proteus (Middelburg, Hans van der Hellen: 1618) fols. 2r-2v: 'dattet zyn stomme beelden, ende nochtans sprekende: gheringhe saken, ende niet-te-min van gewichte: belachelycke dinghen, ende nochtans niet sonder wijsheyt: In de welcke men de goede zeden als met vinghers wysen, ende met handen tasten can, in de welcke (seg ick) men gemeenlyck altyt meer leest, alsser staet: ende noch meer denckt, alsmen siet'.

42 Cats Jacob, Sinne- en Minnebeelden, ed. H. Luijten, 3 vols. (The Hague: 1996) vol. 2, 79-82; Kolfin, Young Gentry 229-232. 
human life, and invited to enhance their godly spirituality through word and image. So Cats's claim about the power of thinking 'still more than one sees' can be found in the verbal and visual messages that help to strengthen the reader's belief, and to guide the value of love between man and woman towards honourable Christian love, with its aversion to worldly enjoyments and sin.

It is noteworthy that the 1637 booklet adopted these didactic complementary images. The private booklet adorned with Cats's didactic emblem would have been an exclusive sign that the marriage of Van Belle and Hespel was legitimized by the zealous Protestant manner of observing the moderation of the spiritual wedding ceremony. It is also an example that shows how didactic emblems like those of Cats impacted on the use of images in Dutch epithalamic booklets, demonstrating that the images had to reflect the Protestant value of a moderate and God-fearing married life.

This particular combination of word and image would have been familiar to the bridal couple and their guests because the images were borrowed from a best-selling emblem book, and the vernacular text is plain and simple, and does not contain any names of mythological figures or intellectual allegories. The images are not directly mentioned in the text, which was written not for the bridal couple but for the bride's mother, and is titled 'An address to the mother'. The poem details a mother's emotions on seeing her children embark on married life, society's essential cornerstone, and preparation for the end of their lives. The text conforms to Cats's warning that an appropriate Calvinist wedding feast should have neither song nor entertainment, but only faithful prayers for the future of the married couple, as the poem ends with the words: 'God wishes to praise the couple, / God who wishes to gladden them both/ Down here on earth, / And attend them with his spirit/ And also crown them in the hereafter/ When his son reveals him.43

Correspondingly, the images prompt the viewers to find the deeper meaning of the instructive messages. The first image is related to a mother's worry that her daughter might be led astray by a silver-tongued rogue and her overriding concern that she choose a suitable partner, accompanied by the image of two trees grafted together and the motto 'Of two one, of one two'.44 This is followed by 'Sweeter after sadness', with a woman and her rejected suitor seated in front

43 Belle Pieter van, Bruylofts ghedicht en ghelvck-vvenschinge over het soet versamen van [...]. Samvel Hespel [...] Clara van Belle (Rotterdam, Pieter van Waesberge: 1637) A6r: 'Godt wil 't Paer ghebenedyden/ God die wilse bey verblyden/ Hier beneden op der aerdt./ Met sijn Geest haer oock by-woonen/ En hier namaels oock bekroonen/ Als sijn Soon hem openbaerdt'.

Cats, Sinne- en minnebeelden 266-271: Iam plenis nubilis annis [45]. 
of a curtained bed, highlighting the importance of prudence and watchfulness before indulging in physical pleasure. ${ }^{45}$ The next, rather gruesome scene of a rotting corpse is titled 'Nobody would suffer longer from lust', and is a memento mori that would have put the dampers on merrymaking at the wedding breakfast, with its reference to Cupid's use of the body's fat as a source of oil for his torch. ${ }^{46}$ This image sent a fervent message to the readers that spirituality and piety are the only virtuous way of life for a sincere Christian, by showing the consequences for the dead body and the nothingness of pursuing fleshly desire. The garden scene with flowers without bees conveyed the message that it was disgraceful for an old man to fall in love. ${ }^{47}$ The emblem of a seagull with its beak trapped shut by an oyster, with the motto 'Who expects to catch is often caught', shows the importance of being watchful and behaving cautiously, with faith and wisdom. ${ }^{48}$ The final one, with garlanded oxen heading for slaughter, proclaims that 'Pleasure is fleeting', urging the guests to be mindful of moderation and godliness, and to never forget that in life we are surrounded by death. ${ }^{49}$

If the entire programme of the 1637 wedding banquet followed the model of Pieter van Belle's epithalamium one imagines that it must have been a very solemn and edifying wedding day, with more than a hint of memento mori about it. The illustrations borrowed from the emblems of the moralist Cats would have served to prepare the mood for a restrained and pious wedding night far removed from the earthy exhortations and glorification of carnal love that typified traditional epithalamia.

The rise and spread of Dutch illustrated epithalamia in the first half of the seventeenth century demonstrates how a literary tradition bowed to the demands of a newly minted Calvinist ethic, and how illustrations accompanying occasional poems underpinned the essential nature of religious marital virtues for Dutch readers, placing all the emphasis on piety, modesty, chastity and restraint on the wedding night. The texts and images of the booklets had been used to tone down the voluptuous mood of nuptial entertainments even before the arrival of bestsellers in the genres of didactic emblem books and conduct books that reflected Calvinist teaching about marital virtues, as can be seen from Cats's publications. This phenomenon tells us that the seventeenth-century Dutch reception of the epithalamic genre was

45 Ibid. 224-229: Post tristia dulcor [38].

46 Ibid. 302-307: Nemo dolens patet libidini [51].

47 Ibid. 194-199: Turpe senilis amor [33].

48 Ibid. 146-151: Qui captat, capitur [25].

49 Ibid. 110-115: Quod iuvat exiguum est [19]. 
positive when it shifted its focus by urging the bridal couple to observe an intensely religious ritual on the wedding night that entailed meditation and prayer in preparation for their joint devotional life together. In that sense, the illustrated epithalamic booklets were no longer ephemera lauding worldly pleasure and festivities, but had the far more serious task of sealing the marital bond with pious pledges.

\section{Bibliography}

Belle Pieter van, Bruylofts ghedicht en ghelvck-vvenschinge over het soet versamen van [...]. Samvel Hespel [...] Clara van Belle (Rotterdam, Pieter van Waesberge: 1637).

Bouman J., Nederlandse gelegenheidsgedichten voor 1700 in de Koninklijke Bibliotheek te 's-Gravenhage (Nieuwkoop: 1982).

Brune Johan de, Emblemata of Zinne-werck (Amsterdam, Jan Evertsen Kloppenburch: 1624).

Cats Jacob, Sinne- en Minnebeelden, ed. H. Luijten, 3 vols. (The Hague: 1996).

Dam H.J. van, "Taking Occasion by the Forelock: Dutch Poetry and Appropriation of Occasional Poems", in Maes Y. (ed.), Appropriation and Latin Literature (Leiden: 2009) 95-127.

D'Elia A., "Marriage, Sexual Pleasure, and Learned Brides in the Wedding Orations of Fifteenth-Century Italy", Renaissance Quarterly 55 (2002) 379-433.

D'Elia A., The Renaissance of Marriage in Fifteenth-Century Italy (Cambridge, MA London: 2004).

Forster L., The Icy Fire. Five Studies in European Petrarchism (Cambridge: 1969).

Franits W., Paragons of Virtue: Women and Domesticity in Seventeenth-Century Dutch Art (Cambridge - New York: 1993).

Geerdink N., "The Appropriation of the Genre of Nuptial Poetry by Katharina Lescailje (1649-1711)", in Gilleir A. (ed.), Women Writing Back / Writing Women Back. Transnational Perspectives from the Late Middle Ages to the Dawn of the Modern Era (Leiden: 2010) 163-200.

Kolfin E., The Young Gentry at Play. Northern Netherlandish Scenes of Merry Companies 1610-1645 (Leiden: 2005).

Schenkeveld-van der Dussen M.A., "Bruilofts - en liefdeslyriek in de 18e eeuw: de rol van de literaire conventies", De Nieuwe Taalgids 67 (1974) 449-461.

Schenkeveld-van der Dussen M.A., "Christus, Hymenaeus of de 'teelzucht", in Witstein S.F. - Grootes E.K. (eds.), Visies op Vondel na 300 (The Hague: 1979) 11-25.

Schenkeveld-van der Dussen M.A., "Poëzie als gebruiksartikel: gelegenheidsgedichten in de zeventiende eeuw", in Spies M. - Berg W. van den (eds.), Historische letterkunde. Facetten van vakoefening (Groningen: 1984) 75-92. 
Steur A. van der, Gelegenheidsgedichten. Los verschenen gedrukte gelegenheidsgedichten op Nederlandse personen, 17e-20e eeuw (Haarlem: 2004).

Tufte V., The Poetry of Marriage. The Epithalamium in Europe and its Development in England (Los Angeles: 1970).

Yang J., "Starter's Contribution to a Frisian Wedding", in Boersma P. - Brand H. Spoelstra J. (eds.), Philologia Frisica Anno 2012 (Leeuwarden: 2014) 155-173.

Yang J., "Trusting Hands: The Dextrarum Iunctio in Seventeenth-Century Dutch Marriage Iconography", Dutch Crossing, on-line publication, Dor:10.1080/03096564.2016.11 39786 . 